\title{
Structural and non-structural carbohydrates in concentrate supplements of silage-based dairy cow rations. 1. Feed intake and milk production
}

\author{
H. DE VISSER ${ }^{1}$, P. L. VAN DER TOGT 2 \& S. TAMMINGA ${ }^{2}$ \\ 1 Research Institute for Livestock Feeding and Nutrition, P.O.Box 160, NL 8200 AD \\ Lelystad, Netherlands \\ 2 Present address: Department of Animal Nutrition, Wageningen Agricultural University, \\ Haagsteeg 4, NL 6708 PM Wageningen, Netherlands
}

Received 7 February 1990; accepted 9 March 1990

\begin{abstract}
A feeding trial was carried out with 64 multiparous dairy cows, in which the effects of type of carbohydrates in concentrate mixtures (starch versus cell wall constituents) and differences in rumen degradation (fast versus slow) on feed intake and milk production were studied. The experiment started immediately after parturition and lasted for 15 weeks. The basal diet which comprised $75 \%$ of the total dry matter (DM) intake, consisted of wilted grass silage, maize silage and concentrates. The remaining part of the diet consisted of barley (B), maize $(\mathrm{M})$, pressed ensiled beet pulp (P) or moist ensiled maize bran (MB). All diets were fed as totally mixed rations (TMR). Total intake of DM and net energy did not differ between diets, but differences were found in energy partition. There was a tendency for cows fed diet B to show increased body weight gain, while cows fed $\mathrm{P}$ mobilized more body reserves, compared to the other treatments. Milk production did not differ between diets, but milk fat content was higher for diet $\mathbf{P}$. Milk protein content was higher for diets $\mathbf{B}$ and $\mathbf{M}$, compared to $\mathrm{P}$ and MB. The lower protein content of the milk of treatment $\mathbf{P}$ can be explained by a longer period of negative energy balance, while the lower milk protein in cows fed diet MB probably resulted from a reduced microbial protein synthesis.
\end{abstract}

Keywords: carbohydrates, dairy cows, intake, milk production

\section{Introduction}

Dairy cows cannot achieve high yields if they are fed with roughages as the only feed. This is especially the case in early lactation, when the needs for energy are high, but roughage intake is limited. This limited capacity to consume roughage necessitates supplementation of dairy diets with concentrates to meet the cow's requirements. In concentrates as well as roughages over $60 \%$ of the organic matter consists of carbohydrates, which consequently are the most important energy source of a dairy cow. 
Carbohydrates are a very heterogeneous group of complex chemical compounds. Van Soest (1982) divided them into constituents originating from plant cell walls or structural carbohydrates (hemicellulose, cellulose, pectins) and constituents originating from the cell contents or non-structural carbohydrates (starches, sugars). Properties of carbohydrates such as rumen solubility, rumen degradability or ruminal rate of degradation are to a large extent determined by their physical structure (crystalline, amorphous) and encrustration or encapsulation with other compounds. Chesson \& Forsberg (1988) reported a large variability in complexity of the chemical composition within different groups of carbohydrates.

Hemicellulose and cellulose are often encrusted by lignin, a complex polymer of phenolic acids, whereas starches are usually stored in granules surrounded by a layer of which the chemical composition and physical structure have not yet been completely elucidated.

Differences in type of carbohydrates and amount fed cause differences in rate of ruminal fermentation (Tamminga et al., 1990), site of digestion in the digestive tract (Waldo, 1973; Sutton, 1985) and total digestion (de Visser \& Steg, 1988). Also differences may occur in type of micro-organisms in the rumen (Russell \& Sniffen, 1984) and pattern of fermentation end products (de Visser \& de Groot, 1980; Sutton et al., 1987; Tamminga et al., 1990). Changes in fermentation end products may subsequently influence milk production and composition (de Visser \& de Groot, 1980; Thomas et al., 1986; Sutton et al., 1987).

De Visser \& de Groot (1980) demonstrated that feeding concentrates with a starch content increasing from 12 to $47 \%$ dramatically influenced rumen fermentation. Large quantities of starch caused high concentrations of short-chain, mainly volatile fatty acids, particularly propionic and lactic acid. This resulted in a severe drop in ruminal $\mathrm{pH}$, which in turn caused rumen acidosis and off-feed. When concentrates containing over $35 \%$ of starch were fed, the number of animals suffering from rumen acidosis increased rapidly. As a result feed intake, milk production and milk fat content were negatively influenced. The starch sources used in those experiments were mixtures of tapioca, hominy feed, maize gluten feed and wheat.

Malestein et al. (1988), Tamminga et al. (1990) and Tamminga (pers. comm.) investigated differences in rumen fermentation characteristics between various types of starch in more detail using in vitro, in sacco and in vivo techniques. Differences in extent of degradation were found between in vivo (Tamminga et al., 1990) and in vitro studies (Malestein et al., 1988), but the ranking in rumen degradability of starches of different origin was very similar. Cell wall constituents vary not only in the rate of rumen degradation, but also in the extent (degradability) because a varying proportion is not available for rumen degradation (Tamminga et al., 1990).

To investigate the practical significance of differences in digestive behaviour of different carbohydrates, a feeding trial was performed with dairy cows in which two types of starch (barley and maize) and two types of cell wall constituents (beet pulp and maize bran) were compared. The objective of the study was to establish effects on feed intake, milk production and milk composition of differences in degradability of carbohydrates measured in the fermentation studies. The feeding experiment was complemented with a study with rumen cannulated dairy cows in which the ef- 
fects on rumen fermentation pattern, in vivo rumen digestion and kinetics and degradation by means of nylon bag incubations were measured. More detailed results of this experiment will be discussed in a subsequent paper, but when relevant, reference will be made to these results in this paper too.

\section{Material and methods}

The feeding trial was performed with 4 groups of 16 animals of the Dutch Black and White or Dutch Black and White $\times$ Holstein breed. All animals were in second or later lactation. The experiment started immediately after parturition and lasted for 15 weeks. The animals were fed equal before parturition according to the advice of the Central Bureau of Nutrition.

Based on previous milk production the animals were grouped into blocks of 4 animals, and within each block allocated at random to one of the four dietary treatments. The basal diet which supplied $75 \%$ of the total dry matter (DM) intake, consisted of wilted grass silage, maize silage and a concentrate mixture. In addition, $25 \%$ of the DM consisted of either barley (B), maize (M), pressed ensiled beet pulp (P) or moist ensiled maize bran (MB). The composition of the diets is shown in Table 1. The composition of the concentrate mixtures is given in Table 2. The diets were offered as a totally mixed ration (TMR) twice daily with $40 \%$ of the daily allowance at 5:00 h and $60 \%$ at 15:00 h. The animals were fed individually and refusals were recorded once daily $(14: 00 \mathrm{~h})$.

Pressed beet pulp, maize bran and concentrates were sampled once a week and analysed for their dry matter (DM) content, whereas wilted grass silage and maize silage were sampled twice a week and also analysed for DM. The week samples of each ration component were subsampled over a monthly period and analysed for their content of ash, nitrogen (N), crude fat, crude fibre, neutral detergent fibre (NDF), sugars, starch and in vitro digestibility of the organic matter. Samples of wilted grass silage, maize silage, pressed beet pulp and moist maize bran were regularly analysed for volatiles, lactic acid and ammonia to enable corrections on dry

Table 1. Diet composition ( $\mathrm{g} \mathrm{kg}^{-1}$ dry matter).

\begin{tabular}{lcccc}
\hline Component & $\begin{array}{l}\text { Barley } \\
\text { (B) }\end{array}$ & $\begin{array}{l}\text { Maize } \\
(\mathrm{M})\end{array}$ & $\begin{array}{l}\text { Pulp } \\
(\mathrm{P})\end{array}$ & $\begin{array}{l}\text { Maize bran } \\
\text { (MB) }\end{array}$ \\
Wilted grass silage & 250 & 250 & 250 & 250 \\
Maize silage & 250 & 250 & 250 & 250 \\
Concentrate barley1 & 500 & - & - & - \\
Concentrate maize $^{2}$ & - & 500 & - & - \\
Concentrate cell wall & - & - & 250 & 250 \\
Pressed ensiled beet pulp & - & - & 250 & - \\
Moist ensiled maize bran & - & - & - & 250 \\
\hline
\end{tabular}

1 Concentrate barley contained $49 \%$ barley (see Table 2 ).

2 Concentrate maize contained $48 \%$ maize (see Table 2 ). 
Table 2. Ingredient composition of the concentrate mixtures ( $\mathrm{g} \mathrm{kg}^{-1}$ product).

\begin{tabular}{lccc}
\hline \multirow{2}{*}{ Component } & \multicolumn{2}{c}{ Concentrate mixture } & \\
\cline { 2 - 4 } & barley & maize & cell wall \\
Potato protein & 40 & 40 & 80 \\
Maize gluten & 40 & 40 & 80 \\
Coconut expeller & 112 & 112 & 215 \\
Linseed expeller & 88 & 88 & 170 \\
Soybean hulls & 58 & 58 & 115 \\
Barley & 490 & - & - \\
Maize & - & 480 & - \\
Animal fat & 10 & - & 10 \\
Soybean meal solv.extr. & 140 & 159 & 10 \\
Calcium carbonate & 7 & 7 & 6 \\
Calcium phosphate & 3 & 5 & 10 \\
Magnesium oxide & 5 & 7 & 14 \\
Premix (vitamins and minerals) & 7 & & 10 \\
\hline
\end{tabular}

matter content and energy value for losses of volatiles. The analytical methods used were as described by Robinson et al. (1986) and de Visser \& Hindle (1990).

During the total experimental period, milk production was recorded daily. Milk samples, taken during 8 consecutive milkings each week, were analysed for fat, protein and lactose (Melk controle station Noord-Nederland). Each week the animals were weighed on 8 consecutive times directly after milking. These data were used to calculate average weekly body weight and body weight changes. The average weekly milk yield, milk composition and body weight were used to calculate energy requirements.

Experimental results were subjected to analysis of variance with the statistical package Genstat (Alvey et al., 1982), using treatment effects within blocks as variables.

\section{Results}

The chemical composition and the energy and protein values of the wilted grass silage, maize silage, concentrate mixtures, pressed beet pulp, moist maize bran and the four TMR diets are shown in Table 3. The results of feed intake and milk production and composition are given in Table 4 and Figures 1 and 2. Summarized data of the rumen fermentation study are shown in Table 5.

Mean total dry matter intake was high (approximately $24 \mathrm{~kg} \mathrm{DM}$ ), but did not differ significantly between diets. However, cows fed diet $\mathrm{P}$ tended to have a lower DM intake, compared to the treatments B, M or MB. Due to the excellent quality of the wilted grass silage (Table 3 ) resulting in a high energy density and the high levels of intake, net energy intake was also high for all diets. Net energy intake did not differ significantly between diets, but intake of diet $\mathrm{P}$ was lowest, due to a somewhat lower DM intake (Table 4) and intake of diet $M$ was highest due to the higher 
Table 3. The chemical composition and feeding value of the wilted grass silage, maize silage, concentrate barley, concentrate maize, concentrate cell wall, pressed beet pulp, moist maize bran, and the four TMR diets.

\begin{tabular}{|c|c|c|c|c|c|c|c|c|c|c|c|}
\hline Ingredient & $\mathrm{DM}^{1}$ & Ash & $\mathrm{N}$ & CFAT & $\mathrm{CF}$ & $\mathrm{NDF}$ & Sugars & Starch & $\begin{array}{l}\mathrm{d}_{\mathrm{OM}} \\
\text { in vitro }\end{array}$ & NEL & DCP \\
\hline Grass silage & 500 & 102 & 35 & 47 & 234 & 451 & 68 & - & 78 & 6.41 & 154 \\
\hline Maize silage & 345 & 51 & 13 & 25 & 220 & 441 & - & 274 & 72 & 6.17 & 44 \\
\hline $\begin{array}{l}\text { Beet pulp } \\
\quad \text { (pressed ensiled) }\end{array}$ & 219 & 71 & 16 & 7 & 202 & 468 & 23 & - & 88 & 7.47 & 63 \\
\hline $\begin{array}{l}\text { Maize bran } \\
\text { (moist ensiled) }\end{array}$ & 383 & 9 & 21 & 33 & 123 & 563 & - & 258 & 88 & 7.48 & 91 \\
\hline Conc. cell wall 2 & 894 & 112 & 56 & 46 & 107 & 289 & 75 & 39 & 83 & 7.48 & 304 \\
\hline Conc. barley ${ }^{3}$ & 874 & 80 & 38 & 38 & 79 & 255 & 55 & 270 & 83 & 7.56 & 196 \\
\hline Conc. maize 4 & 877 & 72 & 39 & 41 & 66 & 211 & 55 & 325 & 86 & 7.84 & 194 \\
\hline Diet barley & 648 & 79 & 31 & 37 & 153 & 351 & 44 & 204 & - & 6.93 & 147 \\
\hline Diet maize & 649 & 74 & 31 & 39 & 147 & 329 & 45 & 231 & - & 7.07 & 146 \\
\hline Diet beet pulp & 489 & 84 & 30 & 31 & 191 & 412 & 42 & 78 & - & 6.88 & 141 \\
\hline Diet maize bran & 530 & 69 & 31 & 38 & 171 & 436 & 36 & 143 & - & 6.89 & 148 \\
\hline
\end{tabular}

$1 \mathrm{DM}=$ dry matter $\left(\mathrm{g} \mathrm{kg}^{-1}\right)$; Ash $\left(\mathrm{g} \mathrm{kg}^{-1} \mathrm{DM}\right) ; \mathrm{N}=$ nitrogen $\left(\mathrm{g} \mathrm{kg}^{-1} \mathrm{DM}\right)$, CFAT = crude fat (g kg-1 DM); CF = crude fibre (g kg $1 \mathrm{DM}) ; \mathrm{NDF}=$ neutral detergent fibre (g kg-1 DM); sugars $\left(\mathrm{g} \mathrm{kg}^{-1} \mathrm{DM}\right) ;$ Starch $\left(\mathrm{g} \mathrm{kg}^{-1} \mathrm{DM}\right) ; \mathrm{d}_{\mathrm{OM}}$ in vitro = digestibility of organic matter in vitro $(\%) ; \mathrm{NEL}=$ net energy lactation ( $\mathrm{MJ} \mathrm{kg-1} \mathrm{DM}$; van Es, 1978); DCP = digestible crude protein (g kg-1 DM).

2 Conc. cell wall $=$ concentrate used in diets $\mathrm{P}$ and $\mathrm{MB}$.

3 Conc. barley $=$ concentrate including $49 \%$ barley.

4 Conc. maize $=$ concentrate including $48 \%$ maize.

energy density (Table 3 ).

Milk production was similar for all treatments, although small differences were found. These differences could be explained by differences in energy intake or changes in body weight (Table 4). Milk fat content was significantly higher $(P<0.05)$ for diet $\mathrm{P}$ compared to diets B, M and MB (Table 4). Milk protein content of cows fed the diets $\mathrm{M}$ and $\mathrm{B}$, which were relatively high in starch, were significantly higher $(P<0.05)$ than those after feeding diets $P$ and MB (Table 4; Fig. 2). The milk protein content on treatment $P$ showed a different pattern during the experiment compared to diet MB. During the first period of the experiment the milk protein content was similar for diets $\mathrm{P}$ and MB, while at the later stage of the trial milk protein content on treatment $\mathbf{P}$ showed an increase towards the higher values measured with diets B and M (Fig. 2). The lactose content of the milk was similar for all diets, although the values were lower for both starch diets. The production ( $\mathrm{g}$ $\mathrm{d}^{-1}$ ) of milk fat, milk protein and lactose did not differ significantly between treatments (Table 4).

Energy ratio (intake as percentage of requirements) was significantly lower $(P<0.05)$ for treatment $\mathrm{P}$ than for $\mathrm{B}$ or $\mathrm{M}$ but similar to MB (Table 4). Differences in the utilization of energy occurred between diet $\mathrm{B}$ and the other diets $\mathrm{M}, \mathrm{P}$ and MB. Cows fed barley showed a reduced milk energy output (PFCM) and an increased body weight gain over the total experimental period, while cows on diet $\mathrm{P}$ 


\section{NEL intake/NEL requirement $(\%)$}

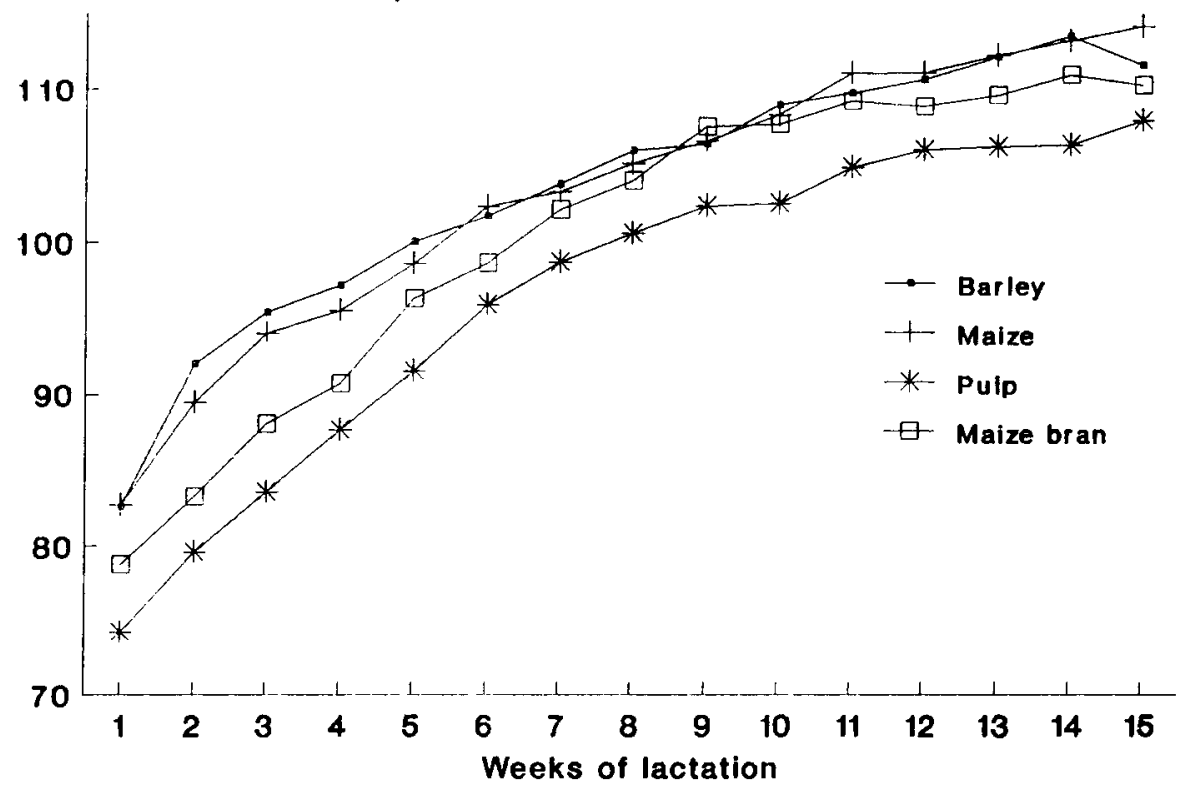

Fig. 1. Time-course of net energy intake requirement ratio.

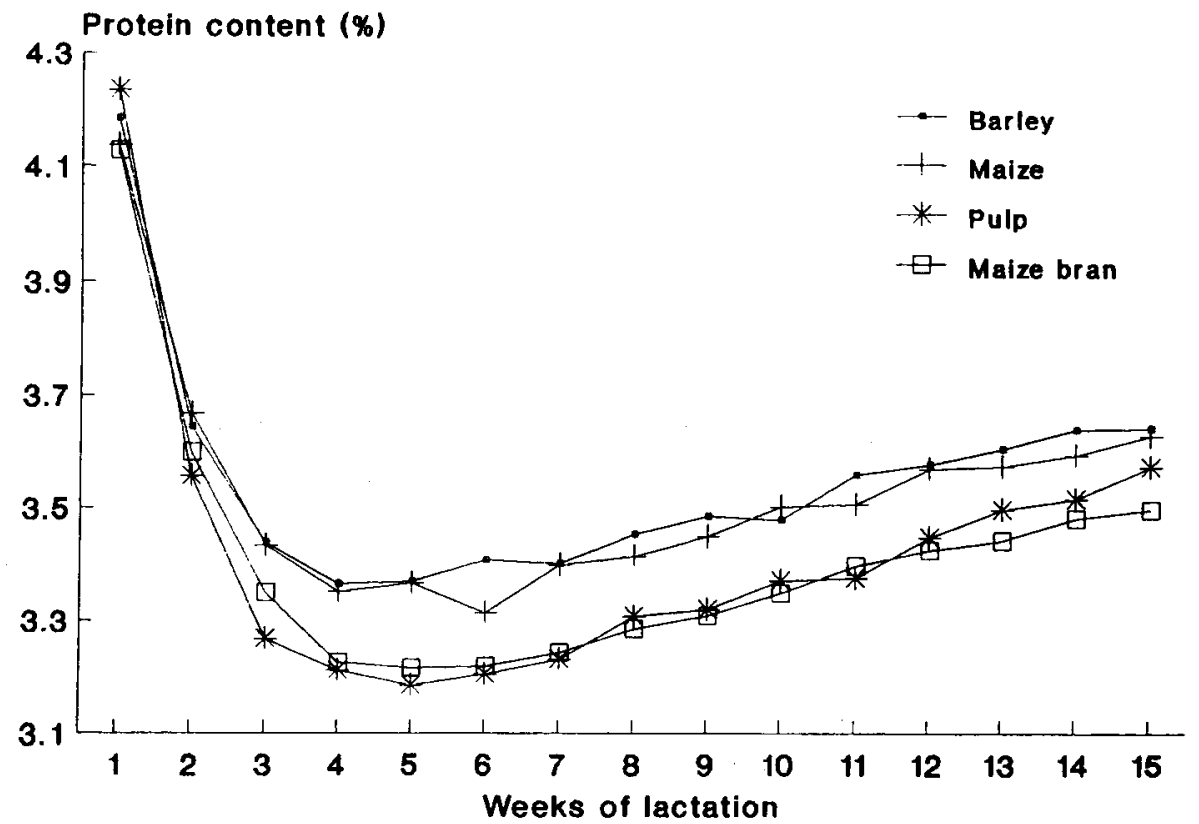

Fig. 2. Time-course of protein content. 
Table 4. Feed intake, milk production, milk composition and body weight changes of the cows during the experimental period of 15 weeks (means of 16 animals).

\begin{tabular}{llllll}
\hline Barley & Maize & Pulp & Maize bran & SED $^{4}$ \\
(B) & (M) & (P) & (MB) &
\end{tabular}

Feed intake

Total dry matter intake $\left(\mathrm{kg} \mathrm{d}^{-1}\right)$

Net energy intake (MJ d-1)

$\begin{array}{ccccc}24.7 & 24.4 & 23.7 & 24.3 & 0.56 \\ 169 & 172 & 163 & 166 & 3.93 \\ 3661 & 3549 & 3298 & 3586 & 90 \\ 107^{\mathrm{a}} & 106^{\mathrm{a}} & 100^{\mathrm{b}} & 102^{\mathrm{ab}} & 2.4 \\ 130^{\mathrm{a}} & 124^{\mathrm{a}} & 113^{\mathrm{b}} & 124^{\mathrm{a}} & 3.3\end{array}$

Energy ratio $(\%)$

DCP ratio $2(\%)$

$130^{2}$

124 a

$\begin{array}{cc}37.1 & 38.2 \\ 38.7 & 39.5 \\ 4.34^{\mathrm{a}} & 4.25^{\mathrm{a}} \\ 3.55^{\mathrm{a}} & 3.53^{\mathrm{a}} \\ 4.65 & 4.67 \\ 1589 & 1610 \\ 1298 & 1335 \\ 1726 & 1782\end{array}$

37.7

38.1

1.27

Milk (kg d-1)

$\operatorname{PFCM}^{3}\left(\mathrm{~kg} \mathrm{~d}^{-1}\right)$

Fat $(\%)$

Protein $(\%)$

Lactose $(\%)$

Fat $\left(\mathrm{g} \mathrm{d}^{-1}\right)$

Protein $\left(\mathrm{g} \mathrm{d}^{-1}\right)$

Lactose $\left(\mathrm{g} \mathrm{d}^{-1}\right)$

1726

40.1

39.7

1.24

$4.54 \mathrm{~b}$

$4.34 \mathrm{a}$

0.08

$3.42^{\mathrm{b}}$

$3.41^{\mathrm{b}}$

0.05

4.71

4.72

0.03

$1700 \quad 1645$

55

$1280 \quad 1292$

37

$1775 \quad 1797$

62

Body weight

Body weight change $(\mathrm{kg})$

$+2$

$-8$

$-19$

$-11$

10

Body weight $(\mathrm{kg})$

602

611

620

608

15

1 Energy ratio $=$ energy intake $/$ energy requirements $\times 100$.

2 DCP ratio $=$ digestible crude protein intake $/$ requirements $\times 100$.

3 PFCM $=$ protein and fat corrected milk.

4 SED $=$ standard error of difference.

ab Figures with a different superscript differ significantly $(P<0.05)$.

Table 5. Rumen fermentation characteristics after feeding concentrates containing carbohydrates of different type and origin.

\begin{tabular}{lccccc}
\hline & $\begin{array}{l}\text { Barley } \\
(\mathrm{B})\end{array}$ & $\begin{array}{l}\text { Maize } \\
(\mathrm{M})\end{array}$ & $\begin{array}{l}\text { Pulp } \\
(\mathrm{P})\end{array}$ & $\begin{array}{l}\text { Maize bran } \\
(\mathrm{MB})\end{array}$ & SED \\
pH & 5.73 & 5.76 & 5.77 & 5.70 & 0.04 \\
Total VFA (mmol 1-1) & 142 & 142 & 145 & 146 & 3.62 \\
NGR' & 3.35 & 3.50 & 3.99 & 3.59 & 0.26 \\
Acetic acid (mmol 1-1) & 86 & 85 & 92 & 90 & 2.75 \\
Propionic acid (mmol 1-1) & 35 & 35 & 32 & 35 & 2.07 \\
Ammonia (mmol l-1) & 7.46 & 8.37 & 7.27 & 9.45 & 0.96 \\
Iso butyrate (mmol 1-1) & 0.8 & 0.8 & 0.8 & 1.0 & 0.09 \\
\hline
\end{tabular}

1 VFA $=$ volatile fatty acids.

2 NGR $=$ non-glucogenic $/$ glucogenic ratio (Orskov, 1975).

Netherlands Journal of Agricultural Science 38 (1990) 
showed the most negative energy balance because of a lower energy intake and a higher milk energy output, resulting in an increased mobilization of body reserves (Table 4; Fig. 1).

\section{Discussion}

High annual milk outputs of dairy cows are only possible with high feed intakes. The first limitation in this respect is often the quality of the roughage, because it largely defines the energy density of the total diet. Energy density of the diets fed in this experiment was high with on average $6.9 \mathrm{MJ} \mathrm{NE} \mathrm{kg-1}$ dry matter.

Dry matter intake was also high and averaged $24.3 \mathrm{~kg} \mathrm{DM} \mathrm{d}^{-1} \mathrm{cow}^{-1}$. Because of differences in dry matter content of around $15 \%$ between diets $\mathrm{P}$ and $\mathrm{MB}$ on the one hand and diets $B$ and $M$ on the other (Table 3), a reduced intake for diets $\mathbf{P}$ and $\mathrm{MB}$ was expected as observed before in other experiments with silage based diets (Lahr et al., 1983; de Visser \& Hindle, 1990). Although the differences in intake reflected the expected pattern, they did not reach significance.

Differences in feed intake were also expected because of expected differences in rumen fermentation pattern between diets. De Visser \& de Groot (1980) observed a reduced feed intake with diets high in starch and sugars $\left(>420 \mathrm{~g} \mathrm{~kg}^{-1} \mathrm{DM}\right) \mathrm{com}-$ pared to diets high in cell wall components. They explained these differences in feed intake by differences in $\mathrm{pH}$, concentration of propionic acid and lactic acid of rumen fluid. When feeding diets high in starch, Malestein \& van 't Klooster (1986) observed a reduced roughage intake when maize starch was replaced by tapioca starch. Tamminga et al. (1990) and Tamminga (pers. comm.) studied rumen fermentation patterns after feeding diets high in tapioca, barley or maize. Rumen fermentation pattern after feeding maize differed from that after feeding barley or tapioca, which were very similar. Feeding barley or tapioca resulted in more propionic and lactic acid, a lower Nonglucogenic Glucogenic Ratio (NGR) and a slower feed intake.

In the experiment reported here, differences in rumen fermentation pattern between diets were present but comparatively small (Table 5). This seems to contradict the earlier findings, but it should be realized that in the experiment of de Visser \& de Groot (1980) considerably higher amounts of starch and sugars per kg DM concentrates were fed $\left(>420 \mathrm{~g} \mathrm{~kg}^{-1} \mathrm{DM}\right)$. Moreover, the amount of roughage fed in the experiments of de Visser \& de Groot (1980) and of Tamminga (pers. comm.) was restricted to between 6 and $7.5 \mathrm{~kg} \mathrm{DM} \mathrm{d}^{-1}$, while in this trial total DM intake of roughage was approximately $12 \mathrm{~kg} \mathrm{DM} \mathrm{d}^{-1}$. Higher amounts of roughage are considered to influence positively buffering capacity, due to increased saliva production.

A further reason why the differences in rumen fermentation pattern in this experiment were only small is the difference in method of feeding. In the experiments of de Visser \& de Groot (1980) and Malestein \& van 't Klooster (1986) roughage and concentrates were fed separately, but in this experiment diets were fed as totally mixed rations. TMR usually result in a more stable rumen fermentation (Rohr \& Schlunsen, 1986).

Additional differences between the experiment reported here and previous experi- 
ments were the quality of the roughage, the level of milk production and the level of feed intake. Roughage quality in the experiment of Malestein \& van 't Klooster (1986) and of Tamminga (pers. comm.) was rather poor and roughage was fed to low producing dairy cows at a medium level of feed intake. Low ruminal $\mathrm{pH}$ affects cellulolytic activity (Russell \& Sniffen, 1984). Therefore it is probable, that the degradation of low-quality roughage, which is high in cellulose and lignine, is more inhibited than that of high quality.

High levels of milk production cause a rapid clearance of VFA from the rumen and may prevent a severe drop in ruminal pH (van der Walt, 1984). Some researchers have reported higher milk productions with barley diets compared to pulp diets (Tremere et al., 1968; Sutton et al., 1987), while others reported lower milk yields (Castle et al., 1981; Thomas et al., 1986; Sutton et al., 1987).

In the experiment reported here, energy intake and milk production did not differ between diets. However, partition of energy did differ, resulting in differences in body weight changes and in milk composition. Cows fed diet $\mathrm{P}$ had a higher fat content in their milk, compared to diets B, M. These findings agreed with the results of Sutton et al. (1987) and Thomas et al. (1986) comparing the effect of concentrates rich in starch with those rich in fibre. The protein content of the milk was significantly higher for diets $\mathrm{B}$ and $\mathrm{M}$, compared to both rations which were high in cell wall constituents ( $P$ and MB). This agreed with the result of Thomas et al. (1986), but disagreed with the results of Sutton et al. (1987) and Castle et al. (1981).

The differences in energy partition can be explained by a number of phenomena, probably occurring simultaneously. The first explanation is a difference in rumen fermentation pattern. Rumen fermentation after feeding diet B, M and MB changed to a higher proportion of propionic acid in the volatile fatty acids (VFA) causing a lower NGR, as is shown in Table 5. This high amount of propionic acid probably caused an increased concentration and/or activity of insulin (Sutton et al., 1980; van Beukelen, 1983) resulting in a change of fat secretion by the mammary gland towards fat deposition in adipose tissue (Vernon, 1988). The resulting lower milk fat contents for diets $M$ and $B$ confirmed earlier findings with comparable diets (de Visser \& de Groot, 1980; van Beukelen, 1983; Thomas et al., 1986; Sutton et al., 1987). In addition, the period the animals were in negative energy balance was longest for animals fed diet P (Fig. 1; Table 4). During negative energy balance, longchain fatty acids are mobilized from adipose tissue and become available for fat synthesis in the mammary gland. During negative energy balance, a larger proportion of milk fatty acids originates from direct incorporation of these long-chain fatty acids into milk fat (Palmquist \& Conrad, 1971); the latter fatty acids are very efficiently utilized by mammary gland tissue (Vernon, 1988).

The lower milk fat content of animals fed diet MB was unexpected, because diet MB contained a large amount of NDF, at least compared to diets B and M (Table 3 ). The findings agree however with the lower NGR values measured in the rumen fermentation study (Table 5). Maize bran has a high content of starch compared to beet pulp (Table 3 ). This starch is relatively rapidly fermentable in the rumen, which may have influenced rumen fermentation pattern towards more propionic acid.

It is noteworthy that the milk fat content of treatment $M$ was lower than that of 
the cows fed diet B, despite the fact that NGR was higher. This apparent discrepancy can be explained by a difference in ruminal behaviour of the starch in both diets. Barley starch is known to be degraded rapidly and almost completely whereas a significant proportion of maize starch usually escapes from fermentation (Waldo, 1973). Starch escaping rumen degradation may become available as glucose after intestinal absorption (Sutton, 1985; MacRae et al., 1988). Barley will be rapidly and extensively degraded in the rumen resulting in a large quantity of the glucogenic precursor propionic acid, but also significant amounts of the lipogenic precursor acetic acid will be produced. As a result the amount of glucogenic precursors will be higher with the maize containing diet.

Both diets rich in cell wall constituents ( $\mathrm{P}$ and $\mathrm{MB}$ ) showed a lower milk protein content than diets $\mathrm{B}$ and $\mathrm{M}$. Considering the milk protein content during the experiment (Fig. 2), a different pattern between diets $P$ and MB was revealed. During the first part of the experiment both diets showed a reduced milk protein content, compared to diets B and M. However, at the last weeks of the experiment the milk protein content after feeding diet $P$ increased towards the values measured with diets $B$ and $M$. At that time, energy intake of the animals fed diet $P$ reached energy balance (Fig. 1). This observation agrees with the results of Broster \& Thomas (1981), who found a positive relationship between energy balance and milk protein content.

Further differences between diets $\mathrm{P}, \mathrm{B}$ and $\mathrm{M}$ on the one hand and diet $\mathrm{MB}$ on the other were the differences in the concentration of ammonia and iso-butyrate of the rumen fluid, which were increased with diet MB, compared to the other diets (Table 5), indicating a reduced microbial protein synthesis. These findings agree with the results of Miller (1982) and Robinson et al. (1987) and might have been responsible for the persistent lower milk protein content of diet MB, compared to the other diets, due to reduced intestinal protein supply.

In conclusion, the results of this study show that high milk yields can be achieved with high-quality diets. Milk composition however can be manipulated by changing the carbohydrate composition of the concentrate part of the diet. The effects of the different cell wall constituents need further research.

\section{References}

Alvey, N., N. Galwey \& P. Lane, 1982. An introduction to Genstat. Academic Press, London, $151 \mathrm{pp}$. Anonymous, 1988. Table on feedstuffs. Information about composition, digestibility and nutritive value. (In Dutch.) Centraal Veevoederbureau in Nederland, Lelystad.

Beukelen, P. van, 1983. Studies on milk fat depression in high producing dairy cows, Doctoral thesis, University of Utrecht, $268 \mathrm{pp}$.

Broster, W. H. \& C. Thomas, 1981. The influence of level and pattern of concentrate input on milk output. In: W. Haresign (Ed.), Recent advances in animal nutrition, p. 49-69. Butterworths, London.

Castle, M. E., M. S. Gill \& J. N. Watson, 1981. Silage and milk production: a comparison between barley and dried sugar-beet pulp as silage supplements. Grass and Forage Science 36: 319-324.

Chesson, A. \& C. W. Forsberg, 1988. Polysaccharide degradation by rumen microorganisms. In: P. N. Hobson (Ed.), The rumen microbial ecosystem, p. 251-284. Elsevier Applied Science, London.

Es, A. J. H. van, 1978. Feed evaluation for ruminants. 1. The system in use from May 1977 onwards 
in the Netherlands. Livestock Production Science 5: 331-335.

Lahr, D. A., D. E. Otterby, D. G. Johnson, J. G. Linn \& G. Lundquist, 1983. Effects of moisture content of complete diets on feed intake and milk production by cows. Journal of Dairy Science 66: 1891-1900.

MacRae, J. C., P. J. Buttery \& D. E. Beever, 1988. Nutrient interactions in the dairy cow. In: P. C. Garnsworthy (Ed.), Nutrition and lactation in the dairy cow, p. 55-75. Butterworths, London.

Malestein, A. \& A. Th. van 't Klooster, 1986. Influence of ingredient composition of concentrates on rumen fermentation rate in vitro and in vivo and on roughage intake of dairy cows. Journal of Animal Physiology and Animal Nutrition 55: 1-13.

Malestein, A., A. Th. van 't Klooster \& J. W. Cone, 1988. Degradability of various types of starch by incubation with rumen fluid or with bacterial -amylase. Journal of Animal Physiology and Animal Nutrition 59: 225-232.

Miller, E. L., 1982. The nitrogen needs of ruminants. Occasional Publication of the British Society of Animal Production 6: 79-88.

Ørskov, E. R., 1975. Manipulation of rumen fermentation for maximum food utilisation. World Review of Nutrition and Dietetics 22: 152-182.

Palmquist, D. L. \& H. R. Conrad, 1971. Origin of plasma fatty acids in lactating cows fed high grain or high fat diets. Journal of Dairy Science 54: 1025-1033.

Robinson, P. H., S. Tamminga \& A. M. van Vuuren, 1986. Influence of declining level of feed intake and varying the proportion of starch in the concentrate on rumen fermentation in dairy cows. Livestock Production Science 15: 173-189.

Robinson, P. H., S. Tamminga \& A. M. van Vuuren, 1987. Influence of wet versus dry by-product ingredients and addition of branched-chain volatile fatty acids and valerate to dairy diets. 2 . Rumen fermentation and milk production. Netherlands Journal of Agricultural Science 35: 447-458.

Rohr, K. \& D. Schlunsen, 1986. The bearing of feeding methods on digestion and performance of dairy cows. In: Neiman-Sorensen (Ed.), New developments and future perspectives in research on rumen function, p. 227-242. ECSC-EEG-EAEC, Brussels.

Russell, J. B. \& C. J. Sniffen, 1984. Effect of carbon-4 and carbon-5 volatile fatty acids on growth of mixed rumen bacteria in vitro. Journal of Dairy Science 67: 987-994.

Soest, P. van, 1982. Nutritional ecology of the ruminant. O \& B books, Corvallis, OR, USA, 374 pp.

Sutton, J. D., 1985. Digestion and absorption of energy substrates in the lactating cow. Journal of Dairy Science 68: 3376-3393.

Sutton, J. D., J. D. Oldham \& I. C. Hart, 1980. Products of digestion, hormones and energy utilization in milking cows given concentrate containing varying proportions of barley or maize. In: $L$. E. Mount (Ed.), Energy metabolism, p. 303-306. Butterworth, London.

Sutton, J. D., J. A. Bines, S. V. Morant, D. J. Napper \& D. I. Givens, 1987. A comparison of starchy and fibrous concentrates for milk production, energy utilization and hay intake by Friesian cows. Journal of Agricultural Science (Cambridge) 109: 375-386.

Tamminga, S., A. M. van Vuuren, C. J. van der Koelen, R. S. Ketelaar \& P. L. van der Togt, 1990. Ruminal behaviour of structural carbohydrates, non-structural carbohydrates and crude protein from concentrate ingredients in dairy cows. Netherlands Journal of Agricultural Science 38: 513-526.

Thomas, C., K. Aston, S. R. Daley \& J. Bass, 1986. Milk production from silage. 4. The effect of the composition of the supplement. Animal Production 42: 315-325.

Tremere, A. W., W. G. Merrill \& J. K. Loosli, 1968. Adaptation to high concentrate feeding as related to acidose and digestive disturbances in dairy heifers. Journal of Dairy Science 51: 1065-1072.

Vernon, R. G., 1988. The partition of nutrients during the lactating cycle. In: P. C. Garnsworthy (Ed.), Nutrition and lactation in the dairy cow, p. 32-52. Butterworths, London.

Visser, H. de \& A. M. de Groot, 1980. The influence of the starch and sugar content of concentrates on feed intake, rumen fermentation, production and composition of milk. In: D. Giesecke, G. Dirksen \& M. Stangassinger (Eds), Proceedings of the IVth International conference on production disease in farm animals, Munich, p. 41-48. Fotodruck Frank OHG, München, FRG.

Visser, H. de \& V. A. Hindle, 1990. Dried beet pulp, pressed beet pulp and maize silage, as substitutes for concentrates in dairy cow rations. 1 . Feeding value, feed intake, milk production and milk composition. Netherlands Journal of Agricultural Science 38: 77-88.

Visser, H. de \& A. Steg, 1988. Utilisation of by-products for dairy cow feeds. In: P. C. Garnsworthy 


\section{H. DE VISSER, P. L. VAN DER TOGT AND S. TAMMINGA}

(Ed.), Nutrition and lactation in the dairy cow, p. 378-394. Butterworths, London.

Visser, H. de \& S. Tamminga, 1987. Influence of wet versus dry by-product ingredients and addition of branched chain fatty acids and valerate to dairy cows. 1. Feed intake, milk production and milk composition. Netherlands Journal of Agricultural Science 35: 163-175.

Waldo, D. R., 1973. Extent and partition of cereal grain starch digestion in ruminants. Journal of Animal Science 37: 1062-1074.

Walt, J. G. van der, 1984. Metabolic interactions of lipogenic precursors in the ruminant. In: F. M. C. Gilchrist \& R. I. Machie (Eds), Herbivore nutrition in the subtropics and tropics, p. 571-593. The Science Press, Craighall. 